\title{
A construção social de uma enfermidade: o caso da lepra na Colômbia
}

\author{
The Social Construction of an Illness: the case of \\ leprosy in Colombia
}

\author{
Laurinda Rosa Maciel \\ Pesquisadora do DAD/COC \\ laurinda@coc.fiocruz.br
}

Diana Obregón Torres Batallas contra la lepra: Estado, medicina y ciencia en Colombia. Medellín: Banco de la República, Fondo Editorial Universidad EAFIT, 2002, 422p.
$\mathrm{D}$ iana Obregón é professora e pesquisadora da Universidade Nacional da Colômbia e seu livro é uma versão mais abrangente de sua tese de doutoramento em história da cência, defendida na Universidade de Virgínia, em 1996. Partindo de um interesse geral sobre a constituição das associações científicas no final do século XIX e início do XX na Colômbia, a autora se surpreendeu com o grande número de artigos sobre lepra, fazendo-a supor que os médicos, na época, não tivessem outra preocupação como foco de atenção e análise. Essa descoberta causou-lhe a princípio verdadeiro horror, sobretudo "... por las figuras que por lo general acompañan las descripciones médicas ...” (p. 11). Embora não constituíssem seu interesse central, a autora não poderia deixar de notar essa presença.

Algum tempo depois, ao se debruçar sobre o desenvolvimento da teoria microbiana e sobre como a bacteriologia influenciou e modificou as práticas médicas na sociedade colombiana, a autora voltou a deparar com a doença. Dessa vez, os grandes nomes da bacteriologia local, como Juan de Dios Carrasquilla e Federico Lleras Acosta, estavam profundamente envolvidos com a pesquisa sobre a lepra. Assim, Diana percebeu que era preciso entender um pouco mais a doença e descobrir que lugar ela ocupara naquela sociedade, qual sua importância no desenvolvimento da bacteriologia. Tudo isso sem perder de vista o potencial estigmatizante, uma vez que a lepra gera transformações nas percepções humanas e nas relações sociais e culturais, pelo aspecto físico que muitos dos pacientes podem apresentar ao longo do tempo, por causa das seqüelas da doença. ${ }^{1}$

Batallas contra la lepra é dividido em oito capítulos. No primeiro, 'El legado de pasado: la lepra medieval', a autora opta por fazer uma retrospectiva da história da lepra a partir da Idade Média. Faz isso porque a maioria do que foi escrito pelos médicos colombianos acerca da doença

\footnotetext{
${ }^{1}$ Vale a pena ressaltar que hoje, tratada a tempo e regularmente com poliquimioterapia, a doença não produz as lesões lepromatosas que durante séculos acompanharam necessariamente os que sofriam de lepra. A partir da prescriç̃o de três antibióticos ingeridos alternadamente, é possível eliminar o bacilo do organismo ao final de 18 meses. Na minha opinião, esse dado, mais o fato de a doença ser no Brasil chamada de hanseníase desde 1976, reduziram consideravelmente a dimensão do estigma secular presente na palavra 'lepra'. É importante também chamar a atenção para o desuso, desde os anos 1960, do isolamento compulsório como método terapêutico, pois sua eficácia científica foi questionada desde o V International Leprosy Congress, realizado em 1958 no Japão. Data daí também a primeira iniciativa no sentido de mudar o nome da enfermidade para 'doença de Hansen', o que se mostrou infrutífero.
} 
remete ao período medieval, numa tentativa de explicação do preconceito e do estigma construídos em relação a enfermidade. Diana Obregón chama a atenção para um dado a meu ver bastante inédito: afirma existir uma associação acentuada entre o estigma criado e a cultura judaico-cristã, que vê os leprosos como herdeiros do estigma bíblico. Segundo ela, não se encontram registros nas culturas muçulmanas que induzam uma segregação obrigatória às vítimas da doença.

O capítulo dois, 'La elefancia en Colombia: entre la caridad y la exclusión, 1775-1880', analisa as práticas médicas, o cuidado e a atenção dedicados aos pacientes no período colonial colombiano e como estes eram tratados pelas instituições religiosas, que historicamente tiveram a primazia no cuidado aos doentes de lepra, com isolamento nos poucos hospitais existentes. O título do capítulo remete a uma particularidade que faz parte da história da doença: o fato de ela ter nomes diferenciados, como elefantíase, por exemplo. Também encontramos na literatura médica brasileira autores desse período que a chamavam assim, provavelmente pela aparência física que assumem alguns doentes. No entanto, isso pode igualmente nos remeter a uma outra questão: a dificuldade de se proceder a um diagnóstico correto da lepra. ${ }^{2}$

No terceiro capítulo, 'La lepra en Noruega y Hawai en el siglo XIX: entre la bacteriología y la epidemiologia', é estudada a construção que se fez da lepra como uma doença infecciosa específica, no final do século XIX. O exemplo da Noruega, que hoje pode soar como impróprio - por representar o modelo de um país que absolutamente não se enquadra nos que são endêmicos de lepra, pois possui índices sociais de primeiro mundo - é bastante interessante graças a dois fatores. O primeiro deles é que a categorização de lepra como uma 'doença tropical' não é apropriada, pois até meados do século XIX ela era considerada endêmica na Noruega, que nada tem a ver com um país tropical. O segundo, a reforçar a importância dessa doença na sociedade de então, é que o descobridor do agente etiológico é um norueguês, Gerhard A. Hansen.

Ao analisar o exemplo do Havaí, a autora discute o que normalmente se chama de 'volta' da doença ao contexto europeu, de onde esteve ausente até o século XVIII. A lepra era doença com grande presença na Europa até os séculos XIV e XV, época em que experimentou um forte decréscimo, muito provavelmente por conta da melhoria das condições higiênicas pelas quais as sociedades passaram a partir de então. Até o século XVIII a doença decresceu, mas no século seguinte, voltou a aumentar o número de casos, possivelmente por obra das expansões colonialistas do século XIX. A lepra é 'redescoberta' e volta a fazer parte do cotidiano europeu. Diana Obregón chama a atenção do quanto os leprosos - que no universo colonizador faziam parte do elemento colonizado e, portanto, próprio de um outro que não o colonizador eram tratados como gente inferior e bárbara, exigindo com isso uma administração mais moral do que propriamente médica. As diferenças de

\footnotetext{
${ }^{2}$ Segundo a autora, na Colômbia, em 1995, os profissionais de saúde de modo geral tinham dificuldade para diagnosticar corretamente a doença e não confundi-la com outras complicações dermatológicas.
} 
modelo de tratamento para a mesma enfermidade ficam claras: onde se aplica o médico, nacionalista como na Noruega, e onde se aplica o moral, colonial e racista, como no Havaí. ${ }^{3}$

Nos capítulos quatro a oito, a autora analisa sob diferentes aspectos a história da doença no contexto colombiano, desde 1880 até 1961. Esse corte cronológico oferece ao leitor uma viagem ao universo da doença que passa por temas desde a pesquisa laboratorial a seu respeito até o término do isolamento compulsório dos pacientes nos hospitais de Agua de Dios e Contratación. Nesse período também pode-se entender o fortalecimento da comunidade médica e o início da disseminação das teorias infecciosas, que levaram à construção e ao fortalecimento de uma geração de leprologistas na sociedade colombiana.

As campanhas antileprosas; a experiência das colônias agrícolas; a discussão sobre a hereditariedade como fator de propensão ou não à doença; a importância de fatores sociais no número de casos; o contexto econômico e sua influência nas pesquisas laboratoriais; o esforço na busca de uma possível vacina, o que representou o início do tratamento químico pelas sulfas —, estes são apenas alguns dos desdobramentos que a autora faz a respeito do tema. São fatores profundamente enriquecidos com a literatura médica oficial. Uma das maiores contribuições, além de todas já citadas, do livro de Diana Obregón, contudo, é a que ela dá ao reconstruir a 'fala' dos pacientes, dando-lhes voz ativa, quando resgata alguns escritos publicados que custaram à autora um trabalho primoroso de busca e análise documental.

Nos capítulos quatro, 'Construcción de autoridad médica: estadísticas y bacteriología, 1880-1905', e sete, 'Auge y decadencia de una comunidad nacional de leprólogos, 1933-1961', a historiadora mostra a constituição do campo científico da leprologia na comunidade médica, a busca de sua afirmação como prática de atuação e sua 'decadência'. Chama a atenção do quanto seu estudo se baseia na concepção de que os enfoques estruturalistas e construtivistas são necessários e inseparáveis. Ela trabalha com o conceito de 'campo científico', elaborado por Pierre Bourdieu, e os processos de negociação entre pares, no sentido de legitimar seu campo de ação e suas teorias. Dessa forma, a união entre poder, conhecimento científico e comunidade médica são fundamentais no contexto analisado por Diana Obregón.

Segundo a autora, um estudo que analise o processo de construção social das doenças deve estar circunscrito a determinado tempo e espaço, além de constituir um amplo processo de negociação entre os elementos da comunidade médica. Assim, Diana Obregón utiliza os estudos de Charles Rosenberg no livro Framing diseases, mostrando o quanto esses processos apresentam historicidade e particularidades. Aliás, ela chama a atenção de como os estudos de construção social de doenças ou epidemias haviam sido elaborados a partir da análise de médicos e/ou profissionais de saúde.

\footnotetext{
${ }^{3}$ Aqui seria interessante lembrar ao leitor as associações entre a aplicação do modelo colonial no Havaí e o grande número de casos de sífilis, doença venérea que pode exigir um tratamento mais moral do que médico. Além do fato de que ambas, lepra e sífilis, em determinado momento da história foram confundidas, por exibirem sua presença na pele do doente. O trabalho de Sérgio Carrara, Tributo à Vênus, é um estudo bastante elucidativo para o caso da sífilis.
} 
Obregón considera que, em relação à lepra, os historiadores ainda hoje guardam certo silêncio, principalmente ao estudar o que ela chama de "... la lepra moderna, es decir, desde su descripción como una enfermedad infecciosa producida por un microorganismo específico, ha sido descuidado por los historiadores professionales" (p. 41). Segundo a autora, na América Latina o que se tem de um modo geral são os trabalhos feitos por médicos ou missionários religiosos. Cita Heráclides César de Souza-Araújo, um dos primeiros leprologistas do Instituto Oswaldo Cruz nos anos 1920 e um dos grandes nomes na história da doença no Brasil, como um exemplo que se enquadra nessa categoria.

A autora finaliza os objetivos de seu estudo afirmando que a história que procurou fazer da doença busca explicar o papel significativo que ela tem, não somente para o desenvolvimento das instituições de saúde pública na Colômbia, mas também sua posição predominante na consolidação da profissão médica. É como se o sujeito do conhecimento, que é a profissão médica, tivesse se formado junto e em relação de reciprocidade com seu objeto, a lepra. Diana Obregón busca lançar novas luzes sobre o papel das doenças nas representações coletivas da sociedade colombiana, além de explorar a intensidade e a amplitude da particularidade histórica da lepra durante o período proposto.

No estudo de Diana Obregón, a categoria médica, o poder do Estado e os que sofrem as ações de ambos, os doentes, se formaram juntos. Constituíramse em uma relação recíproca que traduz a completa interação “... entre el conocimiento médico y los intereses de la profesión, la dinâmica nacional e international de la lucha contra la lepra y las luchas de poder de los médicos, en las cuales la construcción de un concepto moderno de lepra fue elemento destacado" (p. 45).

A contribuição da autora nas áreas de história das doenças, das ciências, da medicina e da cultura é valiosa, de vez que elementos diferenciados podem estar presentes, não só nos trabalhos que objetivam traçar a história do conhecimento médico sobre uma determinada doença, mas também nas representações sociais e no estigma.

Diana Obregón consegue fazer com que o leitor tenha uma grata experiência em conhecer determinada faceta da constituição da medicina colombiana, tão específica mas que, ao mesmo tempo, possui grande relação de proximidade com o contexto brasileiro. A história da doença que ela constrói é instigante, arrojada, muito bem documentada e fundamentada. Apesar do assunto ser um tema que não apaixona de imediato todas as pessoas, o leitor é levado ao fascinante mundo que Diana Obregón apresenta. Dele não consegue sair enquanto não chega ao término da obra. É leitura obrigatória, no meu entender, para todos os que se interessam, não só pela história da lepra, mas pela história da medicina, da ciência e da cultura. É um trabalho feito com seriedade, dedicação e profissionalismo invejáveis. 


\section{REFERÊNCIAS BIBLIOGRÁFICAS}

Carrara, Sérgio

1996

Rosenberg, Charles et al. (orgs.)

1992
Tributo a Vênus: a luta contra a sífilis no Brasil da passagem do século aos anos 40. Rio de Janeiro, Fiocruz.

Framing disease: studies in cultural history.

New Jersey: Rutgers University Press.

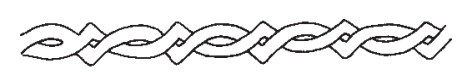


จำ 